\title{
Amphiphilic Cyclotriphosphazenes Grafted with Branched Oligopeptides
}

\author{
Vithal B. Jadhav, ${ }^{\dagger}$ Udaya S. Toti, ${ }^{\dagger}$ Jin Xin Cui, ${ }^{\dagger}$ Yong Joo Jun, ${ }^{\dagger}$ and Youn Soo Sohn* \\ Research Center, C\& Pharm, Natural Science Building B, Ewha Womans University, Seoul 120-750, Korea \\ ${ }^{*}$ E-mail: yssohn@ewha.ac.kr \\ ${ }^{\dagger}$ Department of Chemistry and Nano Science, Ewha Womans University, Seoul 120-750, Korea \\ Received September 16, 2010, Accepted October 26, 2010
}

\begin{abstract}
Branched oligopeptides prepared by coupling a very hydrophobic aspartic diamino acid ethyl ester such as Asp $(\mathrm{LeuEt})_{2}, \mathrm{Asp}(\mathrm{IleEt})_{2}$ and $\mathrm{Asp}(\mathrm{PheEt})_{2}$ to glycine or glycylphenylalanine were grafted to the cyclotriphosphazene backbone bearing an equimolar hydrophilic poly(ethylene glycol) (PEG). The properties of the resultant amphiphiles were examined in comparison with those of the linear oligopeptide analogues previously reported. All cyclic phosphazene trimers grafted with the branched tetra- and pentapeptides displayed a normal trend of thermosensitivity depending on their hydrophilic to hydrophobic balance, but the stability and particle size of their micelles were found to be greatly dependent on the fine structure of the branched oligopeptides grafted. The trimers bearing branched tetrapeptides with a low hydrophobicity were found to form unstable micelles initially, which reassemble into thermodynamically more stable polymersomes.
\end{abstract}

Key Words: Branched oligopeptide, Cyclotriphosphazenes, Micelles

\section{Introduction}

Polymeric micelles have attracted much attention during last decades because of their potential applications as drug delivery systems. ${ }^{1-6}$ Consequently, a tremendous amount of efforts has been made to develop micellar drugs using versatile approaches, which were reported in many excellent reviews. ${ }^{7-12}$ Polymeric micelles are mostly prepared from linear diblock or triblock copolymers consisting of both hydrophilic and hydrophobic segments. Such linear amphiphilic copolymers can easily form spherical micelles by self-assembly in aqueous solution, which however rarely satisfy simultaneously all of the physicochemical properties required for practical drug delivery applications. In particular, the stability and drug loading capacity of the micelles self-assembled from linear block copolymers are the most important problems to overcome for drug delivery via intravenous injection. Therefore, it is an urgent task to exploit new types of amphiphilic polymers.

Recently, we have developed a new method to prepare tripodal amphiphiles, represented as $[\mathrm{N}=\mathrm{P}(\mathrm{X})(\mathrm{Y})]_{3}$, by cis-nongeminally grafting equimolar amounts of a hydrophilic poly (ethylene glycol) (X) and a linear hydrophobic oligopeptide (Y) to a cyclic phosphazene template. ${ }^{13-15} \mathrm{We}$ have demonstrated in our previous study that these tripodal amphiphiles provide strong intra- and intermolecular hydrophobic interactions tunable for self-assembly to various nanostructures such as micelles, bilayered polymersomes, and molecular gels that are ruled by the hydrophobicity parameter $(\log \mathbf{P})$ of the oligopeptides employed. In particular, we have shown that the tripodal cyclotriphosphazenes bearing linear oligopeptides with high hydrophobicity ( $\log \mathbf{P}>1)$ remain as stable micelles in aqueous solution but those with intermediate hydrophobicity $(0<\log \mathbf{P}<1)$ reassemble into bilayered polymersomes. ${ }^{15-17}$

Now it seems very interesting to examine the morphology and physicochemical properties of the tripodal cyclotriphosphazenes with branched oligopeptides instead of linear oligopeptides, and here we report their synthesis and properties.

\section{Experimental}

Materials. Hexachlorocyclotriphosphazene (Aldrich) was used without further purification. The branched tetrapeptide ethyl esters, [GlyAsp(PheEt) 2], [GlyAsp(IleEt) $)_{2}$ ] and [GlyAsp $(\mathrm{LeuEt})_{2}$ ], and a pentapeptide ethyl ester [GlyPheAsp(PheEt) ${ }_{2}$ ] was prepared by the literature method. ${ }^{18}$ Methoxy poly(ethylene glycols) with molecular weights of 350, 550 and 750 (MPEG350, MPEG550 and MPEG750, respectively) (Fluka) were used without further purification but thoroughly vacuumdried and then stored over molecular sieve 4A before use. Tetrahydrofuran (THF) was dried by boiling at reflux over sodium metal and benzophenone and then distilled under a nitrogen atmosphere. Chloroform and triethylamine were dried by boiling at reflux over sodium hydride and barium oxide, respectively and then distilled under the same condition.

Instruments and measurements. ${ }^{1} \mathrm{H}$ NMR spectra were recorded using Bruker DPX-250 NMR spectrophotometer operating at $250 \mathrm{MHz}$ in the Fourier transform mode. Proton-decoupled ${ }^{31}$ P NMR spectra were measured with Varian Unity INOVA-400 spectrophotometer operating at $400 \mathrm{MHz}$ using phosphoric acid as an external standard. Elemental analysis was carried out with a Carlo Ebra-EA1108. The lower critical solution temperature (LCST) was measured by UV-visible spectroscopy. Dynamic light scattering (DLS) measurements were performed for $0.3 \%$ trimer solutions using Malvern Zetasizer (Nano-ZS). The critical micelle concentrations of cyclic trimers were measured by a fluorescence probe technique using pyrene. ${ }^{19}$ TEM images of a trimer deposited on 200 mesh carbon-coated $\mathrm{Cu}$ grid by evaporation of its $0.125 \%$ aqueous solution were measured by JEM-2100F.

\section{Synthesis and characterization.}

$\left.\left.[\text { NP(MPEG350)(GlyAsp(LeuEt) })_{2}\right)\right]_{3}$ (1): The sodium salt of methoxy poly(ethylene glycol) with a molecular weight of 350 (MPEG350) was prepared by reaction of MPEG350 (3.62 g, $10.35 \mathrm{mmol})$ with sodium hydride $(0.26 \mathrm{~g}, 10.87 \mathrm{mmol})$ in THF $(150 \mathrm{~mL})$ at room temperature for $8 \mathrm{~h}$. The solution was filtered 
over argon atmosphere to remove unreacted sodium hydride and was added drop wise to hexachlorocyclotriphosphazene $(1.0 \mathrm{~g}, 2.88 \mathrm{mmol})$ dissolved in THF $(100 \mathrm{~mL})$ at $-70^{\circ} \mathrm{C}$. The reaction was continued for $2 \mathrm{~h}$ at $-70{ }^{\circ} \mathrm{C}$ and then for $8 \mathrm{~h}$ at room temperature. To the reaction solution was slowly added a solution of GlyAsp(LeuEt) $)_{2}(4.49 \mathrm{~g}, 9.5 \mathrm{mmol})$ and triethylamine (1.92 g, $20 \mathrm{mmol})$ dissolved in THF $(100 \mathrm{~mL})$. The reaction mixture was stirred for 2 days at $50{ }^{\circ} \mathrm{C}$ and then filtered to remove solid by-products $\left(\mathrm{NEt}_{3} \cdot \mathrm{HCl}\right.$ and $\left.\mathrm{NaCl}\right)$. After the filtrate was evaporated, the concentrate was precipitated using a solvent pair of THF and n-hexane, which was repeated twice. The resultant product was further purified by dialysis for one day against methanol and another day against ultra-pure water using cellulose dialysis membrane (MWCO: 1000). The dialyzed solution was freeze-dried to obtain the trimer [NP(MPEG$350)\left(\right.$ GlyAsp $\left.\left.(\mathrm{LeuEt})_{2}\right)\right]_{3}$. The product was further purified by precipitation from its aqueous solution $(10 \%)$ at its LCST. Yield: $38 \%$.

Elemental Analysis (\%) Calcd for $\mathrm{C}_{111} \mathrm{H}_{210} \mathrm{~N}_{15} \mathrm{O}_{45} \mathrm{P}_{3} \cdot 3 \mathrm{H}_{2} \mathrm{O}$ : C, 50.85; H, 8.30; N, 8.01. Found: C, 50.83; H, 8.12; N, 8.27. ${ }^{1} \mathrm{H}$ NMR $\left(\mathrm{CDCl}_{3}, \mathrm{ppm}\right) \delta$ 0.87-0.91 (m, 36H, $\left(\mathrm{Leu}-\left(\mathrm{CH}_{3}\right)_{2}\right)$, $1.16-1.5\left(\mathrm{t}, 18 \mathrm{H}\right.$ (Leu-OCH$\left.{ }_{2} \mathrm{CH}_{3}\right)$ and (m, $18 \mathrm{H}$, Leu-CHCH$\left.{ }_{2}^{-}\right)$, 2.7-2.9 (t, 6H, Asp- $\left.\mathrm{CH}_{2}-\right), 3.35$ (s, 9H, (MPEG350- $\left.\overline{\mathrm{OCH}}_{3}\right)$, 3.45-3.55 (b, 78H, MPEG350-OCH $\mathrm{CH}_{2}-$ and d, 6H, Gly$\mathrm{CH}_{2}$ ), 3.97 (b, 6H MPEG350-OCH 2 -O-), 4.1-4.2 (m, 12H, Leu$\overline{\mathrm{OCH}_{2}} \mathrm{CH}_{3}$ ), 4.48 \& 4.92 (b, 9H, (Leu-CH) $)_{2}$ and Asp-CH), 4.76, $7.05,7.99(\mathrm{~m}, 9 \mathrm{H}$, amide $\mathrm{H}$ of peptide $) .{ }^{3 \mathrm{I}} \mathrm{P} \mathrm{NMR}\left(\mathrm{CDCl}_{3}, \mathrm{ppm}\right)$ $\delta$ 21.8. LCST: $41{ }^{\circ} \mathrm{C}$.

[NP(MPEG350)(GlyAsp(IleEt) $\left.\left.)_{2}\right)\right]_{3}$ (2): MPEG350 (3.62 g, $10.35 \mathrm{mmol})$, sodium hydride $(0.26 \mathrm{~g}, 10.87 \mathrm{mmol})$ hexachlorocyclotriphosphazene ( $1 \mathrm{~g}, 2.88 \mathrm{mmol})$, GlyAsp(IleEt) $)_{2}(4.49 \mathrm{~g}$, $9.5 \mathrm{mmol})$ and triethylamine $(1.92 \mathrm{~g}, 20 \mathrm{mmol})$ were used. Yield: $42 \%$.

Elemental Analysis (\%) Calcd for $\mathrm{C}_{111} \mathrm{H}_{210} \mathrm{~N}_{15} \mathrm{O}_{45} \mathrm{P}_{3} \cdot 3 \mathrm{H}_{2} \mathrm{O}$ : C, 50.85; H, 8.30; N, 8.01. Found: C, 50.23; H, 7.95; N, 7.81. ${ }^{1} \mathrm{H} \mathrm{NMR}\left(\mathrm{CDCl}_{3}, \mathrm{ppm}\right) \delta$ 0.87-0.91 (m, 36H, $\left(\mathrm{Ile}-\left(\mathrm{CH}_{3}\right)_{2}\right), 1.16-$ $1.5\left(\mathrm{t}, 18 \mathrm{H}\left(\mathrm{Ile}-\mathrm{OCH}_{2} \mathrm{CH}_{3}\right)\right.$ and $\left(\mathrm{m}, 18 \mathrm{H}\right.$, Ile- $\left.\mathrm{CHCH}_{2}-\right), 2.7-2.9$ $\left(\mathrm{t}, 6 \mathrm{H}, \mathrm{Asp}-\mathrm{CH}_{2}-\right), 3.35\left(\mathrm{~s}, 9 \mathrm{H},\left(\mathrm{MPEG} 350-\overline{\mathrm{OCH}}_{3}\right), 3.45-3.55\right.$ (b, 78H, MPEG350-OCH ${ }_{2} \mathrm{CH}_{2}$ and d, 6H, Gly- $\mathrm{CH}_{2}$ ), 3.97 (b, 6H MPEG350-OCH $\left.\mathrm{OCH}_{2}-\mathrm{O}\right), 4.1-4.2\left(\mathrm{~m}, 12 \mathrm{H}\right.$, Ile-O $\left.\mathrm{CH}_{2} \mathrm{CH}_{3}\right)$, $4.48 \& 4.92$ (b, 9 $\overline{\mathrm{H},}$ (Ile-CH) ${ }_{2}$ and Asp-CH), 4.76, $7.05,7.99$ $(\mathrm{m}, 9 \mathrm{H}$, amide $\mathrm{H}$ of peptide $) .{ }^{31} \mathrm{P}$ NMR $\left(\mathrm{CDCl}_{3}, \mathrm{ppm}\right) \delta 21.9$. LCST: $37^{\circ} \mathrm{C}$.

[NP(MPEG350)(GlyAsp(PheEt) $\left.)_{2}\right)_{3}$ (3): MPEG350 (3.62 g, $10.35 \mathrm{mmol})$, sodium hydride $(0.26 \mathrm{~g}, 10.87 \mathrm{mmol})$ hexachlorocyclotriphosphazene (1 g, $2.88 \mathrm{mmol})$, GlyAsp(PheEt $)_{2}(5.13 \mathrm{~g}$, $9.5 \mathrm{mmol})$ and triethylamine (1.92 g, $20 \mathrm{mmol})$ were used. Yield: $39 \%$.

Elemental Analysis (\%) Calcd for $\mathrm{C}_{129} \mathrm{H}_{198} \mathrm{~N}_{15} \mathrm{O}_{45} \mathrm{P}_{3} \cdot 5 \mathrm{H}_{2} \mathrm{O}$ : C, 53.80; H, 7.35; N, 7.30. Found: C, 54.0; H, 7.58; N, 7.27. ${ }^{1} \mathrm{H}$ $\left.\mathrm{NMR}\left(\mathrm{CDCl}_{3}, \mathrm{ppm}\right) \delta 1.02-1.10\left(\mathrm{t}, 18 \mathrm{H}, \mathrm{Phe}-\mathrm{OCH}_{2} \mathrm{CH}_{3}\right)_{2}\right), 2.5-$ 2.7 (m, 6H, Asp- $\left.\mathrm{CH}_{2}-\right), 2.95$ (m, 12H, Phe- $\left.\mathrm{CH}_{2}-\right), 3.28(\mathrm{~s}, 9 \mathrm{H}$, MPEG350-OCH 3 ), 3.45-3.55 (b, 90H, MPEG350-OCH $\mathrm{CH}_{2}-$ and d, $\left.6 \mathrm{H}, \mathrm{Gly}-\mathrm{CH}_{2}\right), 4.1-4.2\left(\mathrm{~m}, 12 \mathrm{H}\right.$, Phe- $-\mathrm{OCH}_{2} \mathrm{CH}_{3}$ and $6 \mathrm{H}$ MPEG350-OC $\left.\mathrm{H}_{2}-\mathrm{O}-\right)$, 4.63-4.66 (b, 9H, (Phe-CH$)_{2}$ and Asp$\mathrm{CH}), 6.8,7.55,7.64-7.67,7.82-7.85(\mathrm{~d}, 12 \mathrm{H}$, amide $\mathrm{H}$ of peptide), 7.08-7.19 (m, 30H Phe-arom). ${ }^{31} \mathrm{P} \mathrm{NMR}\left(\mathrm{CDCl}_{3}, \mathrm{ppm}\right) \delta$ 22.0. LCST: $19^{\circ} \mathrm{C}$.
[NP(MPEG350)(GlyPheAsp(PheEt) $\left.\left.)_{2}\right)\right]_{3}$ (4): MPEG350 (3.62 g, $10.35 \mathrm{mmol})$, sodium hydride $(0.26 \mathrm{~g}, 10.87 \mathrm{mmol})$ hexachlorocyclotriphosphazene ( $1 \mathrm{~g}, 2.88 \mathrm{mmol})$, GlyPheAsp $\left.(\mathrm{PheEt})_{2}\right)(6.53 \mathrm{~g}, 9.5 \mathrm{mmol})$ and triethylamine (1.92 g, $\left.20 \mathrm{mmol}\right)$ were used. Yield: $42 \%$.

Elemental Analysis (\%) Calculated for $\mathrm{C}_{156} \mathrm{H}_{225} \mathrm{~N}_{18} \mathrm{O}_{48} \mathrm{P}_{3}$ : C, 58.31; H, 7.06; N, 7.85; Found: C, 58.04; H, 6.77; N, 8.17. ${ }^{1} \mathrm{H}$ $\mathrm{NMR}\left(\mathrm{CDCl}_{3}, \mathrm{ppm}\right) \delta$ 0.98-1.04 (t, $\left.\left.18 \mathrm{H}, \mathrm{Phe}-\mathrm{OCH}_{2} \mathrm{CH}_{3}\right)_{2}\right), 2.5-$ 2.7 (m, 6H, Asp- $\left.\mathrm{CH}_{2}-\right), 2.95$ (m, 18H, Phe- $\left.\mathrm{CH}_{2}-\right), 3.28$ (s, 9H, MPEG350-OCH 3 ), 3.45-3.55 (b, 78H, MPEG350-OCH ${ }_{2} \mathrm{CH}_{2}-$ and $\left.\mathrm{d}, 6 \mathrm{H}, \mathrm{Gly}-\mathrm{CH}_{2}\right), 4.1-4.2\left(\mathrm{~m}, 12 \mathrm{H}\right.$, Phe- $\mathrm{OCH}_{2} \mathrm{CH}_{3}$ and $6 \mathrm{H}$ MPEG350-OC $\overline{\mathrm{H}_{2}-\mathrm{O}-}$ ), 4.61-4.68 (b, 12H, (Phe-CH$)_{2}$ and Asp$\mathrm{CH}), 6.9,7.55,7.64-7.67,7.82-7.85(\mathrm{~d}, 15 \mathrm{H}$, amide $\mathrm{H}$ of peptide), 7.08-7.19 (m, 45H Phe-arom). ${ }^{31} \mathrm{P} \mathrm{NMR}\left(\mathrm{CDCl}_{3}, \mathrm{ppm}\right)$ $\delta$ 22.62. LCST: $19^{\circ} \mathrm{C}$.

[NP(MPEG550)(GlyPheAsp(PheEt) $\left.\left.)_{2}\right)\right]_{3}$ (5): MPEG550 (5.69 g, $10.35 \mathrm{mmol})$, sodium hydride (0.26 g, $10.87 \mathrm{mmol})$, hexachlorocyclotriphosphazene (1 g, $2.88 \mathrm{mmol})$, GlyPheAsp $(\mathrm{PheEt})_{2}(6.53 \mathrm{~g}, 9.5 \mathrm{mmol})$ and triethylamine (1.92 g, $\left.20 \mathrm{mmol}\right)$ were used. Yield: $48 \%$.

Elemental Analysis (\%) Calculated for $\mathrm{C}_{186} \mathrm{H}_{285} \mathrm{~N}_{18} \mathrm{O}_{63} \mathrm{P}_{3}$ : C, 57.66; H, 7.41; N, 6.51; Found: C, 56.40; H, 7.33; N, 6.67. ${ }^{1} \mathrm{H}$ $\left.\mathrm{NMR}\left(\mathrm{CDCl}_{3}, \mathrm{ppm}\right) \delta 1.03-1.10\left(\mathrm{t}, 18 \mathrm{H}, \mathrm{Phe}-\mathrm{OCH}_{2} \mathrm{CH}_{3}\right)_{2}\right), 2.6-$ 2.7 (m, 6H, Asp- $\left.\mathrm{CH}_{2}-\right), 3.03$ (m, 18H, Phe- $\left.\mathrm{CH}_{2}-\right), 3.37$ (s, 9H, MPEG550-OCH $\mathrm{OCH}_{3}$, 3.50-3.7 (b, 138H, MPEG350-OCH $\mathrm{CH}_{2}-$ and d, $6 \mathrm{H}, \mathrm{Gly}-\mathrm{CH}_{2}$ ), 3.9-4.2(b, 12H, Phe-OCH $\mathrm{CH}_{3}$ and $6 \mathrm{H}$ MPEG550-OC $\left.\mathrm{H}_{2}-\mathrm{O}-\right), 4.61-4.80(\mathrm{~b}, 12 \mathrm{H} \text {, (Phe-CH})_{2}$ and Asp$\mathrm{CH}), 7.30-8.00$ (d, 15H, amide $\mathrm{H}$ of peptide), $7.20(\mathrm{~m}, 45 \mathrm{H}$ Phe-arom). ${ }^{31} \mathrm{P}$ NMR $\left(\mathrm{CDCl}_{3}\right.$, ppm) $\delta 21.55$. LCST: $51{ }^{\circ} \mathrm{C}$.

[NP(MPEG750)(GlyPheAsp(PheEt) $\left.)_{2}\right)_{3}$ (6): MPEG350 (7.76 g, $10.35 \mathrm{mmol})$, sodium hydride $(0.26 \mathrm{~g}, 10.87 \mathrm{mmol})$, hexachlorocyclotriphosphazene ( $1 \mathrm{~g}, 2.88 \mathrm{mmol})$, GlyPheAsp $(\mathrm{PheEt})_{2}(6.53 \mathrm{~g}, 9.5 \mathrm{mmol})$ and triethylamine (1.92 g, $\left.20 \mathrm{mmol}\right)$ were used. Yield: $28 \%$.

Elemental Analysis (\%) Calculated for $\mathrm{C}_{210} \mathrm{H}_{333} \mathrm{~N}_{18} \mathrm{O}_{75} \mathrm{P}_{3}$ : C, 57.29; H, 7.62; N, 5.73; Found: C, 56.34; H, 7.56; N, 5.49. ${ }^{1} \mathrm{H}$ $\mathrm{NMR}\left(\mathrm{CDCl}_{3}, \mathrm{ppm}\right) \delta$ 0.96-1.01 (t, $\left.\left.18 \mathrm{H}, \mathrm{Phe}-\mathrm{OCH}_{2} \mathrm{CH}_{3}\right)_{2}\right), 2.6-$ 2.7 (m, 6H, Asp- $\left.\mathrm{CH}_{2}-\right), 2.8$ (m, 18H, Phe- $\left.\mathrm{CH}_{2}-\right), 3.26$ (s, 9H, MPEG550-OCH ${ }_{3}$ ), 3.50-3.7 (b, 186H, MPEG350-OC $\underline{\mathrm{CH}}_{2} \underline{\mathrm{CH}}_{2}-$ and d, $\left.6 \mathrm{H}, \mathrm{Gly}-\mathrm{CH}_{2}\right), 3.9-4.2\left(\mathrm{~b}, 12 \mathrm{H}\right.$, Phe- $\mathrm{OCH}_{2} \mathrm{CH}_{3}$ and $6 \mathrm{H}$ MPEG550-OC $\overline{\mathrm{H}_{2}-\mathrm{O}-}$ ), 4.30-4.70 (b, 12H, (Phe-CH$)_{2}$ and Asp$\mathrm{CH}), 7.30-8.00(\mathrm{~d}, 15 \mathrm{H}$, amide $\mathrm{H}$ of peptide $), 7.10(\mathrm{~b}, 65 \mathrm{H}$ Phe-arom). ${ }^{31} \mathrm{P}$ NMR $\left(\mathrm{CDCl}_{3}\right.$, ppm) $\delta 22.38$. LCST: $69{ }^{\circ} \mathrm{C}$.

\section{Results and Discussion}

Synthesis and properties. The amphiphilic cyclotriphosphazene derivatives bearing a methoxy poly(ethylene glycol) (MPEG) as a hydrophilic group and a branched oligopeptide as a hydrophobic group were prepared according to the following reaction Scheme 1 as reported in our previous works. ${ }^{14,15}$

The branched tetra- and pentapeptides were prepared by coupling a very hydrophobic aspartic diamino acid ethyl ester such as Asp(LeuEt) 2 , Asp(IleEt) $)_{2}$ and Asp(PheEt $)_{2}$ to glycine or glycylphenylalanine. ${ }^{18}$ No significant difference was observed in the reactivity of the branched oligopeptides compared with linear oligopeptides as a substituent nucleophile, although more steric hindrance among the branched oligopeptide groups is 

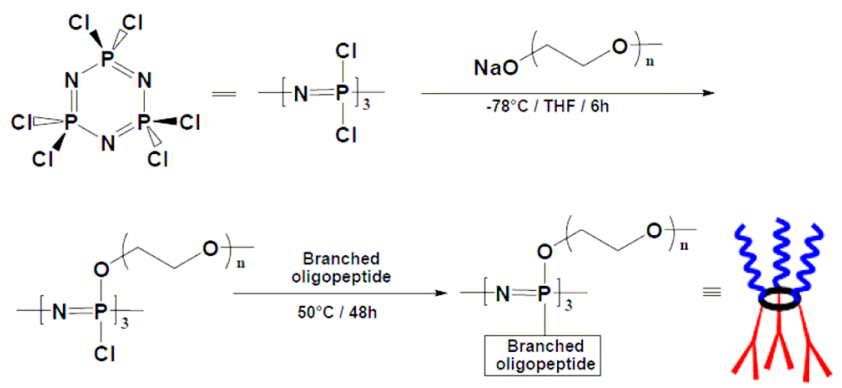

Branched oligopeptide employed;

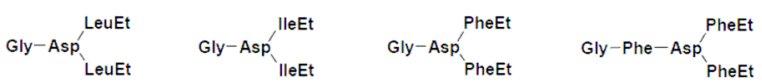

Scheme 1. Synthetic route to micellar cyclotriphosphazenes

(a)

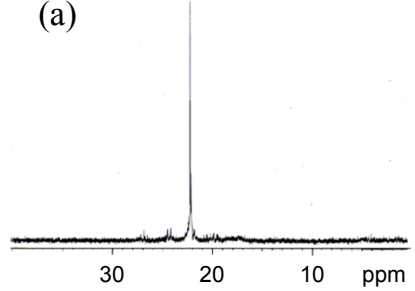

(b)

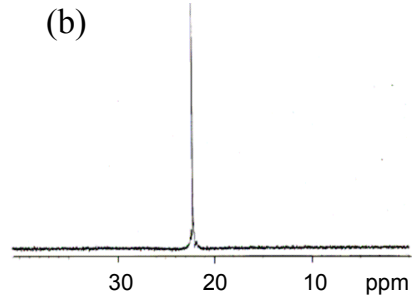

Figure 1. ${ }^{31} \mathrm{P}$ NMR spectra of trimer $\mathbf{1}$ before (a) and after purification (b).

expected for their nucleophilic substitution in the cyclic phosphazene ring compared with the linear oligopeptide groups. We could obtain reasonably high purity ( $>95 \%$ ) of $c i s$-nongeminal conformation of the branched oligopeptides after column purification as shown in the ${ }^{31} \mathrm{P}$ NMR spectra in Figure 1.

We have prepared several derivatives grafted with branched oligopeptides by structural variations of both hydrophilic PEG and hydrophobic branched oligopeptide groups. The solution properties of these amphiphilic trimers such as the lower critical solution temperature (LCST), dynamic light scattering (DLS), and critical micelle concentration (CMC) were measured in aqueous solutions and are listed in Table 1 along with the calculated values of the hydrophobicity parameter, $\log \mathbf{P}$ of the oligopeptide used. ${ }^{20}$ As seen in the table, all cyclotriphosphazenes bearing equimolar amounts of a hydrophilic PEG and a hydrophobic branched oligopeptide exhibit thermosensitive properties by showing a lower critical solution temperature (LCST).

LCSTs of the tetrapeptide-grafted trimers 1-3 with the same PEG350 in the table show that the trimer with the more hydrophobic oligopeptide exhibits lower LCST, as expected. The trimers 4-6 grafted with the same pentapeptide also show a normal trend by displaying the higher LCST as the hydrophilicity of the PEG group increases. It may be pointed out that trimers 1 and $\mathbf{4}$ exhibit an LCST quite lower than body temperature and may be useful for local drug delivery.

In order to examine the morphology of the cyclic trimers grafted with branched-oligopeptides, we have performed dynamic light scattering (DLS) measurements for their aqueous solutions along with a TEM study for trimer $\mathbf{2}$. As seen in the table, the cyclic trimers grafted with branched oligopeptides display their micelle sizes with a mean diameter in the range of 10 to $24 \mathrm{~nm}$ comparable to those of the trimers with linear oligopeptides. ${ }^{14}$ However, it has been found that the branched oligopeptide-grafted trimers show different solution behaviors, which will be discussed in more detail in the next section.

One of the most important properties of polymeric micelles for drug delivery via intravenous injection is the critical micelle concentration (CMC), because the injected micelle-encapsulated drug may be uncapsuled by dilution in the blood system. Therefore, we have measured CMC of the cyclic trimers by a fluorescence probe technique using pyrene, ${ }^{19}$ as demonstrated in Figure 2 and the CMC values are also listed in Table 1.

Comparing the $\mathrm{CMC}$ values of the branched tetrapeptidegrafted trimers 1 to 3 with the same hydrophilicity (MPEG350), it is surprising that these trimers bearing different oligopeptides only with a little different hydrophobicity $(\log \mathrm{P})$ display very large differences in CMC values. In particular, trimers $\mathbf{1}$ and $\mathbf{2}$ are isostructural compounds with little difference in hydrophobicity as shown in the table, but a big difference in micelle stability is observed probably due to even slight structural difference of the terminal amino acid groups. In other words, the terminal isoleucine may be structurally more favorable than leucine in hydrophobic packing of the oligopeptide groups into the micelle core. Another tetrapeptide-grafted trimer $\mathbf{3}$ and all the branched pentapeptide-grafted trimers 4 to 6 with high hydrophobicity seem to self-assemble into stable micelles without further reassembly, as expected.

Table 1. Characteristic properties of cyclotriphosphazene derivatives with different side groups

\begin{tabular}{|c|c|c|c|c|c|c|}
\hline \multirow{2}{*}{$\begin{array}{c}\text { Trimer } \\
\text { No. }\end{array}$} & \multirow{2}{*}{ Molecular formula } & \multirow{2}{*}{$\begin{array}{c}\mathrm{LCST}^{a} \\
\left({ }^{\circ} \mathrm{C}\right)\end{array}$} & \multirow{2}{*}{$\begin{array}{c}\mathrm{DLS}^{b} \\
(\mathrm{~nm})\end{array}$} & \multirow{2}{*}{$\begin{array}{l}\mathrm{CMC}^{c} \\
(\mathrm{mg} / \mathrm{L})\end{array}$} & \multicolumn{2}{|c|}{ Hydrophobicity $(\log \mathrm{P})^{d}$} \\
\hline & & & & & MPEG & Peptide \\
\hline 1 & {$\left[\mathrm{NP}(\mathrm{MPEG} 350)\left(\mathrm{GlyAsp}(\mathrm{LeuEt})_{2}\right)\right]_{3}$} & 41 & 10.5 & 203.0 & -1.36 & $-0.17 \pm 0.49$ \\
\hline 2 & {$\left[\mathrm{NP}(\mathrm{MPEG} 350)\left(\mathrm{GlyAsp}(\mathrm{IleEt})_{2}\right)\right]_{3}$} & 37 & 12.3 & 78.6 & -1.36 & $-0.02 \pm 0.49$ \\
\hline 3 & {$\left[\mathrm{NP}(\mathrm{MPEG} 350)\left(\text { GlyAsp }(\mathrm{PheEt})_{2}\right)_{3}\right.$} & 18 & 16.1 & 11.2 & -1.36 & $0.81 \pm 0.49$ \\
\hline 4 & {$\left[\mathrm{NP}(\mathrm{MPEG} 350)\left(\text { GlyPheAsp }(\mathrm{PheEt})_{2}\right)\right]_{3}$} & 19 & 24.0 & 26.7 & -1.36 & $1.96 \pm 0.49$ \\
\hline 5 & {$\left[\mathrm{NP}(\mathrm{MPEG} 550)\left(\text { GlyPheAsp }(\mathrm{PheEt})_{2}\right)\right]_{3}$} & 51 & 12.8 & 15.3 & -2.50 & $1.96 \pm 0.49$ \\
\hline 6 & {$\left[\mathrm{NP}(\mathrm{MPEG} 750)\left(\text { GlyPheAsp }(\mathrm{PheEt})_{2}\right)\right]_{3}$} & 69 & 12.9 & 14.1 & -2.80 & $1.96 \pm 0.49$ \\
\hline
\end{tabular}

${ }^{a}$ The lower critical solution temperature measured by UV-visible spectroscopy. ${ }^{b}$ The mean diameter of the particles measured for $0.3 \%$ solutions at $20{ }^{\circ} \mathrm{C}$ by dynamic light scattering method except for trimer $\mathbf{3}$ and $\mathbf{4}$, which were measured for $0.25 \%$ solution at $10^{\circ} \mathrm{C}$. ${ }^{c}$ The critical micelle concentrations measured at ambient temperature. ${ }^{d}$ The hydrophobicity defined by $\log \mathbf{P}$ where $\mathbf{P}=[\text { solute }]_{\text {n-octanol }} /[\text { solute }]_{\text {water }}$. 


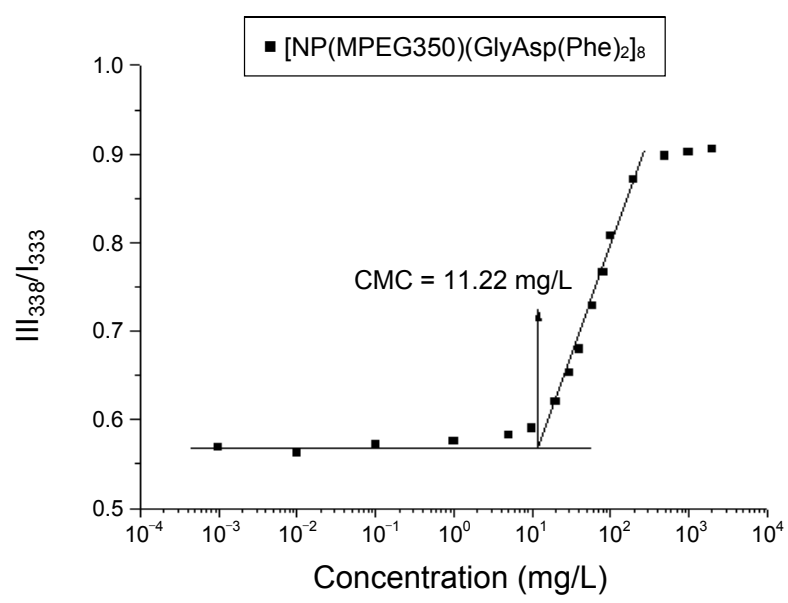

Figure 2. An exemplified determination of the critical micelle concentration of trimer 3 .

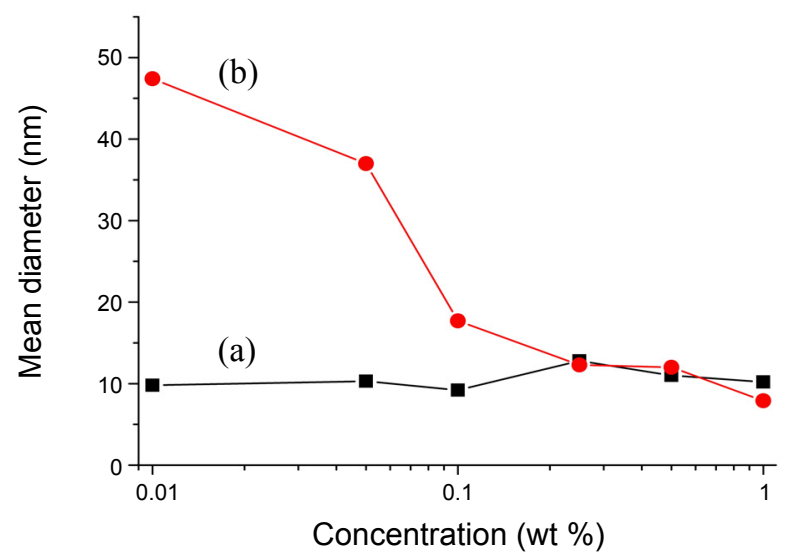

Figure 3. Particle sizes of trimer 5 (a) and trimer 2 (b) dependent on their concentrations.

Morphology. The particle sizes of the trimers given in Table 1 are the data measured by DLS for fresh aqueous solutions containing 0.3 or $0.25 \mathrm{wt} \%$ trimers. However, we have measured both time- and concentration-dependent change of their particle size to find very interesting results. Trimer $\mathbf{3}$ and trimers 4-6 bearing branched oligopeptides with a high hydrophobicity ( $\log \mathrm{P}=0.81$ and 1.96 , respectively) displayed a consistent micelle size independent of time and their concentration with a low CMC values of $11.2 \sim 26.7 \mathrm{mg} / \mathrm{L}$, as shown in Table 1 . On the other hand, trimers $\mathbf{1}$ and $\mathbf{2}$ with low hydrophobicity $(\log \mathrm{P}=$ -0.17 and -0.02 , respectively) were found to exhibit both timeand concentration-dependent particle sizes. We have measured the particle sizes of representative trimers $\mathbf{2}$ and $\mathbf{5}$ with variation of their concentrations from 0.01 to $1.0 \mathrm{wt} \%$ in distilled water and the results were plotted in Figure 3.

The figure shows that trimer 2 forms reasonably good micelles in relatively concentrated $(>0.3 \mathrm{wt} \%$ ) solution but the micelles expand in dilute solution in contrast to nearly constant micelle size of trimer $\mathbf{5}$. Similarly trimer 1 also showed expanded particle sizes on dilution. The exact mechanism of the micelle size expansion of trimers $\mathbf{1}$ and $\mathbf{2}$ on dilution seems not clearly explainable, but it seems to be related with their micelle in- (a)

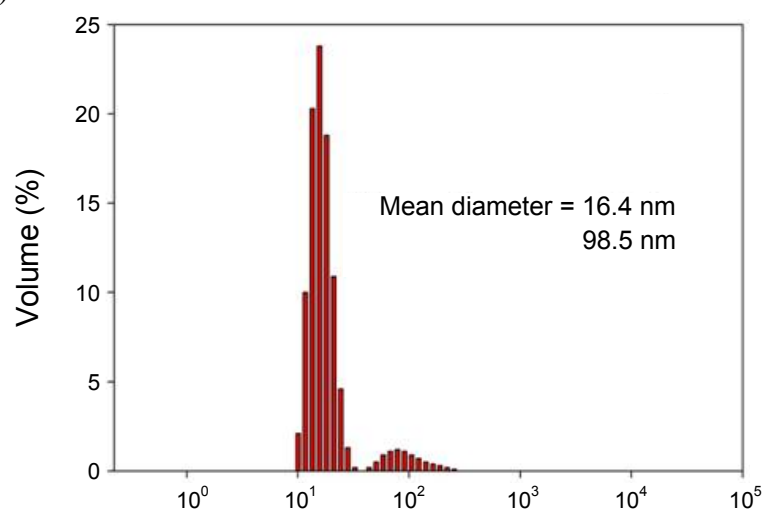

(b)

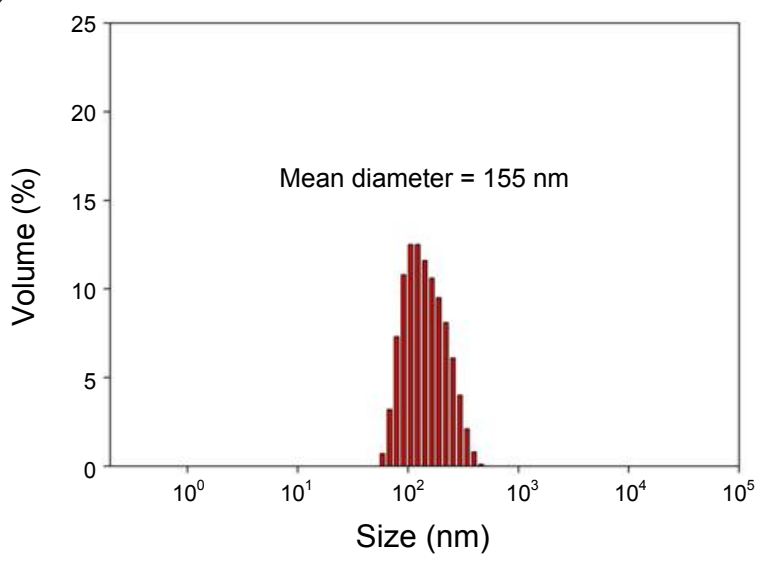

Figure 4. Particle size distributions of fresh (a) and 2 days-old solutions (b) of $0.1 \%$ trimer 2.

stability reflected by their high CMC values shown in Table 1. More interesting aspect found from our time-dependent study is that these trimers $\mathbf{1}$ and $\mathbf{2}$ slowly reassemble from their initially formed micelles $(10 \sim 20 \mathrm{~nm})$ into polymersomes of a larger particle size $(100 \sim 200 \mathrm{~nm})$ in dilute solution $(<0.1 \mathrm{wt} \%)$. We have monitored the time-dependent particle size of trimer $\mathbf{2}$ at $0.1 \mathrm{wt} \%$ concentration, which is shown in Figure 4 . The fresh solution of trimer 2 shows a major distribution (92\%) at around $16.2 \mathrm{~nm}$ and a minor distribution $(8 \%)$ at $98.5 \mathrm{~nm}$, but after 2 days only larger particles were observed at around $155 \mathrm{~nm}$.

We have studied the morphology of these large particles by means of transmission electron microscopy (TEM). The TEM image of trimer 2 deposited on 200 mesh carbon-coated $\mathrm{Cu}$ grid by evaporation of its $0.1 \%$ aqueous solution is shown in Figure 5 . The TEM image in the figure clearly shows polymersomes (black rings) with an inner void and numerous micelles around each of the polymersomes. The darker shades around each polymersome seem to be the reassembling zone where the micelles start to merge to form a polymersome. The polymersomes formed from the trimers bearing the linear oligopetides turned out to form a rigid and thick bilayer due to the close packing of the linear oligopeptides, which was not transparent to the electronic beam and no inner void was seen in the TEM image. ${ }^{15}$ However, the present trimers bearing branched oligopeptides seem to form a coarsely packed bilayer, which is almost 


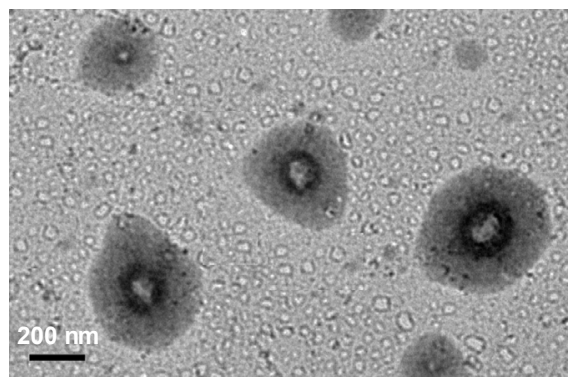

Figure 5. TEM image of trimer $\mathbf{2}$ deposited on a carbon-coated $\mathrm{Cu}$ grid.

transparent to the electronic beam and empty inner space is clearly seen in the TEM image.

Polymersomes are a new class of vesicular nanostructure self-assembled from amphiphilic polymers mimicking liposomes and regarded as one of the most important emerging biomaterials. ${ }^{21-23}$ However, most of polymersomes reported so far are composed of linear block copolymers and encountered many difficulties in preparation, structural stability, biodegradability, drug loading capacity, etc. for practical drug delivery applications. ${ }^{24-27}$ Most recently, we have reported novel polymersomes self-assembled from new tripodal amphiphiles. ${ }^{15} \mathrm{We}$ have demonstrated that the trimers bearing linear oligopeptides with intermediate hydrophobicity $(0<\log \mathrm{P}<1)$ reassemble into polymersomes while trimers with highly hydrophobic oligopeptide $(\log \mathrm{P}>1)$ stay as stable micelles. The branched oligopeptides grafted to the present trimers $\mathbf{1}$ and $\mathbf{2}$ have slightly negative values ( -0.17 and -0.02 , respectively) of hydrophobicity parameter $\log \mathrm{P}$, but considering their standard deviation $( \pm 49)$, they may be regarded to be in the range of intermediate hydrophobicity $(0<\log \mathrm{P}<1)$ for polymersomes. The branched oligopeptide of trimer 3 has a $\log \mathrm{P}$ value of 0.8 , but considering its standard deviation again, also trimer $\mathbf{3}$ may be regarded to be in the range of stable micelles $(\log \mathrm{P}>1)$. Therefore, the present trimers bearing branched oligopeptides seem to follow our hydrophobicity rule.

Finally, it seems interesting to compare the morphology of the present amphiphilic cyclic phosphazenes with that of linear polyphosphazene analogues. Although we have not synthesized the polyphosphazenes bearing the same branched oligopeptides employed in this study, we have already reported that amphiphilic polyphosphazenes bearing hydrophobic linear oligopeptides such as [NP(MPEG350)(GlyPheLeuEt) $]_{\mathrm{n}}$ and [NP (MPEG350)(GlyPheLeuGlyEt) ] n form good thermogels instead of micelles or polymersomes probably due to random hydrophobic interactions among the hydrophobic oligppeptides grafted to the polyphosphazene backbone to make good hydrophobic junctions for cross-linked network. ${ }^{27}$

\section{Conclusions}

We have synthesized new amphiphilic cyclotriphosphazenes grafted with branched tetra- and pentapeptides prepared by coupling a very hydrophobic aspartic diamino acid ethyl ester such as $\mathrm{Asp}(\mathrm{LeuEt})_{2}, \mathrm{Asp}(\mathrm{IleEt})_{2}$ and $\mathrm{Asp}(\mathrm{PheEt})_{2}$ to glycine or glycylphenylalanine. All the present trimers bearing branched oligopeptides displayed a normal trend of thermosensitivity depending on their hydrophilic to hydrophobic balance, but the stability and particle size of their micelles were found to be greatly dependent on the fine structure of the branched oligopeptides grafted. Among the present cyclotriphosphazenes, trimers 1 and $\mathbf{2}$ bearing branched oligopeptides with intermediate hydrophobicity and a high critical micelle concentration were found to reassemble from initially formed micelle to larger polymersomes.

Acknowledgments. This work was supported by the SRC program of the National Research Foundation of Korea Grant funded by the Korean Government (2010-0001488) and by Seoul R \& BD Program (10816).

\section{References}

1. Bae, Y.; Kataoka, K. Adv. Drug Deliv. Rev. 2009, 61, 768.

2. Hur, K. M.; Min, H. S.; Lee, S. C.; Lee, H. J.; Kim, S.; Park, K. J. Control. Release 2008, 126, 122

3. Letchford, K.; Burt, H. Eur. J. Pharm. Biopharm. 2007, 65, 259.

4. Zhang, J. X.; Li, X. J.; Qiu, L. Y.; Li, X. H.; Yan, M. Q.; Jin. Y.; Zhu, K. J. J. Control. Release 2006, 116, 322.

5. Soga, O.; van Nostrum, C. F.; Fens, M.; Rijcken C. J. F.; Schiffellers, R. M.; Storm, G.; Hennink, W. E. J. Control. Release 2005, 103,341

6. Allcock, H. R.; Powell, E. S.; Chang, Y. Macromolecules 2004, 37,7163 .

7. Matsumura, Y. Adv. Drug Deliv. Rev. 2008, 60, 899.

8. Otsuka, H.; Nagasaki, Y.; Kataoka, K. Adv. Drug Deliv. Rev. 2003, $55,403$.

9. Lavasanifar, A.; Samuel, J.; Kwon, G. S. Adv. Drug Deliv. Rev. 2002, 54, 169.

10. Torchilin, V. P. J. Control. Release 2001, 73, 137.

11. Kataoka, K.; Harada, A.; Nagasaki, Y. Adv. Drug Deliv. Rev. 2001, $47,113$.

12. Rösler, A.; Vandermeulen, G. W. M.; Klok, H.-A. Adv. Drug Deliv. Rev. 2001, 53, 95.

13. Jun, Y. J.; Toti, U. S.; Kim, H. Y.; Yu, J. Y.; Jeong, B.; Jun, M. J.; Sohn, Y. S. Angew. Chem. Int. Edit. 2006, 45, 6173.

14. Toti, U. S.; Moon, S. H.; Kim, H. Y.; Jun, Y. J.; Kim, B. M.; Park, Y. M.; Jeong, B.; Sohn, Y. S. J. Control. Release 2007, 119, 34.

15. Jun, Y. J.; Park, M. K.; Jadhav, V. B.; Song, J. H.; Chae, S. W.; Lee, H. J.; Park, K. S.; Jeong, B.; Choy, J. H.; Sohn, Y. S. J. Control. Release 2010, 142, 132.

16. Discher, D. E.; Ahmed, F. Annu. Rev. Biomed. Eng. 2006, 8, 323.

17. Discher, D. E.; Eisenberg, A. Science 2002, 297, 967.

18. Greenstein, J. D.; Winitz, M. Chemistry of the Amino Acids; John Wiley and Sons: New York, 1961; pp 925-942.

19. Inoue, T.; Chen, G.; Nakamae, K.; Hoffman, A. S. J. Control. Release 1998, 51, 221

20. Viswanadhan, V. N.; Ghose, A. K.; Revankar, G. R.; Robins, R. K. J. Chem. Inf. Comput. Sci. 1989, 29, 163.

21. Discher, B. M. ; Won, Y.-Y.; Ege, D. S.; Lee, J. C.-M.; Bates, F. S.; Discher, D. E.; Hammer, D. A. Science 1999, 284, 1143.

22. Discher, D. E.; Ortiz, V.; Srinivas, G.; Klein, M. L.; Kim, Y.; Christian, D.; Cai, S.; Photos, P.; Ahmed, F. Prog. Polym. Sci. 2007, 32,838 .

23. Pang, Z.; Lu, W.; Gao, H.; Hu, K.; Chen, J.; Zhang, C.; Gao, X.; Jiang, X.; Zhu, C. J. Control. Release 2008, 128, 120.

24. Ahmed, F.; Pakunlu, R. I.; Brannan, A.; Bates, F.; Minko, T.; Discher, D. E. J. Control. Release 2006, 116, 150.

25. Xu, J.-P.; Ji, J.; Chen, W.-D.; Shen, J.-C. J. Control. Release 2005 , 107,502

26. Bermudez, H.; Brannan, A. K.; Hammer, D. A.; Bates, F. S.; Discher, D. E. Macromolecules 2002, 35, 8203.

27. Seong, J.-Y.; Jun, Y. J.; Jeong, B; Sohn, Y. S. Polymer 2005, 46, 5075. 